\title{
Prediction of High Performance Liquid Chromatography Retention Time for Some Organic Compounds Based on Ab initio QSPR Study
}

\author{
Hirjani $^{1^{\star}}$, Harno Dwi Pranowo ${ }^{2}$, Mudasir $^{2}$ \\ ${ }^{1}$ Department of Agricultural Engineering, Faculty of Food and Agricultural Technology, University of Mataram, Lombok \\ 83125, Indonesia \\ ${ }^{2}$ Department of Chemistry, Universitas Gadjah Mada, Sekip Utara, Yogyakarta 55281, Indonesia \\ ${ }^{*}$ Corresponding author.E-mail addresses: hirjani@unram.ac.id
}

Received December 20, 2017; Accepted January 12, 2018

\begin{abstract}
Analysis of the quantitative relationship between structure and characteristics of 18 polyaromatic hydrocarbons has been done by quantum Ab initio Quantitative Structure-Property Relationship (QSPR) study at Hartree Fock level of theory. Moment dipole was used as the quantum chemical descriptors, whereas molecular weight and number of rings were applied for constitutional descriptor and the valence connectivity index as steric descriptors. The compound's electronic structure was studied by molecular modeling and retention time $(\mathrm{Tr})$ data was obtained from literature. Multilinear regression analysis has been performed by randomly splitting the initial data set into on fitting data set and a test data set. The best result provided by QSPR analysis is the following model equation:
\end{abstract}

$\log \mathrm{t}_{R}=1.276+0.016 \mathrm{MW}+0.323 R \mathrm{c}-0.423 \mathrm{x}^{1}-0.147 \mathrm{x}^{2}$ with $\mathrm{n}=18 \mathrm{r}=0.917 \mathrm{r}^{2}=0.841$

$\mathrm{SE}=0.182 \quad \mathrm{~F}_{\text {cald }} / \mathrm{F}_{\text {table }}=5.408$.

The retention times of PAH compounds with two and three rings were successfully predicted by QSPR models.

Keywords: QSPR, Retention Times, PAH compounds, Ab initio

ABSTRAK

Telah dilakukan analisis waktu retensi kromatografi pada suhu ruangan menggunakan perhitungan metode $A b$ initio pada tingkatan teori Hartree Fock. Deskriptor kimia kuantum yang digunakan adalah momen dipol, deskriptor konstitusional berupa berat molekul dan jumlah cincin. Data perhitungan struktur elektronik senyawa diperoleh setelah prosedur optimasi geometri dengan sedangkan data waktu retensi $\left(t_{R}\right)$ diperoleh dari literatur. Analisis dilakukan terhadap data awal yang dipisahkan secara acak menjadi data fitting dan data uji dengan metode regresi multilinier. Hasil analisis QSPR memberikan model persamaan terbaik adalah:

$\log t_{R}=1,276+0,016 M W+0,323 R c-0,423 x^{1}-0,147 x^{2}$ dengan $n=18 r=0,917 r^{2}=0,841$

$\mathrm{SE}=0,182$ Fhitung $/$ Ftabel $=5,408$.

Model QSPR yang diperoleh dapat memprediksi waktu retensi senyawa PAH dengan cincin dua dan tiga.

Kata kunci: QSPR, Waktu Retensi, Senyawa PAH, Ab initio

\section{PENDAHULUAN}

Poliaromatik hidrokarbon (PAH) merupakan salah satu kontaminan lingkungan yang berbahaya, dikarenakan sifatnya yang beracun, tahan lama, dan karsinogenik, maka sumber dan distribusi PAH dalam suatu wilayah telah menjadi perhatian utama dalam penelitian, baik di wilayah perairan, tanah maupun udara. Analisis senyawa PAH melibatkan sejumlah komponen asing yang dapat mengganggu dalam analisis, sehingga komponen pengganggu tersebut perlu dihilangkan sebelum senyawa diidentifikasi. Di antara berbagai teknik pemisahan yang tersedia, kromatografi merupakan metode pemisahan yang sering digunakan dan luas dalam aplikasinya. Teknologi analisis dengan kromatografi banyak digunakan untuk menganalisis senyawa organik, salah satunya adalah pemisahan dengan Kromatografi Cair Kinerja Tinggi atau High Performance Liquid Chromatography (HPLC). Prinsip kerja HPLC adalah molekul yang berbeda akan tertahan pada waktu yang berbeda dalam kolom kromatografi sesuai dengan polaritas struktur molekulnya.

Analisis dengan HPLC ini mempunyai beberapa kelebihan seperti mudah dioperasikan dan mempunyai kapasitas pemisahan yang tinggi sehingga metode 
analisis ini dijadikan sebagai preferensi dalam hal identifikasi molekul senyawa organik. Selain itu untuk mendeteksi senyawa PAH lebih banyak dilakukan dengan menggunakan instrumen HPLC dibandingkan dengan kromatografi. Di samping kelebihan yang ada, HPLC juga memiliki kelemahan yakni sering mengalami kesulitan dalam mengidentifikasi dengan tepat seluruh puncak kromatogram pada pemisahan. Hal ini terjadi terutama untuk kromatogram senyawa $\mathrm{PAH}$ yang puncaknya saling tumpang tindih satu dengan lainnya sehingga memungkinkan hasil keseluruhannya berupa kekeliruan identifikasi molekul.

QSPR (Quantitative Structure-Property Relationship) adalah salah satu aplikasi dari kimia komputasi yang digunakan sebagai solusi memprediksi puncak kromatogram dari HPLC. Metode QSPR banyak digunakan dalam mengembangkan sebuah model untuk input waktu retensi dari berbagai senyawa hidrokarbon dalam kolom kromatografi (5-16). Hasil penelitian yang dilakukan tersebut menunjukkan adanya korelasi yang baik antara hasil prediksi QSPR dengan waktu retensi eksperimen. Prediksi hubungan kuantitatif antara struktur molekul dan sifat fisikokimia untuk memprediksi waktu retensi telah banyak dilakukan. Akan tetapi, penelitian mengenai prediksi struktur molekul dengan waktu retensi pada kromatografi cair dengan metode kimia komputasi $a b$ initio masih jarang ditemukan. $A b$ initio merupakan salah satu metode yang memberikan hasil perhitungan yang lebih akurat dibandingkan hasil perhitungan metode lainnya seperti semiempirik. Kenyataan keakuratan $A b$ initio dibandingkan semiempirik terlihat jelas saat melakukan perhitungan pada atom atau molekul yang bermuatan. Berdasarkan uraian tersebut, maka akan dilakukan penelitian kajian QSPR untuk memprediksi waktu retensi kromatografi cair kinerja tinggi beberapa senyawa PAH. Penelitian ini bertujuan untuk mencari model persamaan QSPR dari 18 senyawa $\mathrm{PAH}$ dengan menggunakan metode kimia komputasi ab initio.

\section{BAHAN DAN METODE}

\section{Peralatan}

Dalam penelitian ini digunakan peralatan komputer dengan processor Intel $₫$ core TM 2 quad CPU Q670, memori 4GB, hardisk $160 \mathrm{~GB}$, dengan sistem operasi linux openSUSE. Perangkat lunak (Software) kimia komputasi yang digunakan dalam adalah Gausview 03 for windows, Gaussian 03 under linux, Gabedit 2.4.3, Modeslab 1.5, Chemcraft 1.6 built 356, dan SPSS 16.00 for Windows.

\section{Objek Penelitian}

Bahan yang digunakan dalam penelitian ini adalah data struktur molekul dari eksperimen waktu retensi HPLC yang berasal dari literatur [17].

\section{Perhitungan Deskriptor-deskriptor}

Optimasi struktur senyawa menggunakan metode $A b$ initio Hartree-Fock dengan basis set terpilih 6-31G. Optimasi dilakukan dengan terlebih dahulu menggambar struktur dari masing-masing senyawa $\mathrm{PAH}$ dalam bentuk 3D dengan menggunakan program gaussview. Gambar yang dihasilkan dengan program gaussview tersebut berupa "text file" yang memiliki ekstensi gjf (gaussian job file) dan sesuai untuk gaussian dengan sistem operasi windows. Oleh karena komputasi (running) dilakukan dengan gaussian untuk linux maka file tersebut harus diubah terlebih dahulu. Pengubahan input file ini dilakukan dengan program gabedit yang dapat mengubah ekstensi file dari gjf menjadi .com. Kemudian file .com ini dihitung menggunakan metode yang telah dipilih. Setelah itu dilakukan perhitungan terhadap deskriptor kimia kuantum yang berupa momen dipol

Untuk perhitungan deksriptor sterik yang terdiri dari indeks konektivitas valensi orde 1 dan 2 dilakukan dengan menggunakan program modesleb dengan memasukkan SMILES senyawa ke dalam program terus tekan "ok" maka otomatis nilai dari indeks konektivitas valensi keluar, sedangkan untuk deskriptor konstitusional seperti berat molekul dan jumlah cincin dapat dihitung secara manual atau secara komputasi dengan perangkat lunak.

\section{Analisis Regresi Multilinier}

Metode yang digunakan pada evaluasi QSPR adalah analisis regresi multilinier dengan menggunakan program SPSS 16.0 menggunakan metode backward dan enter. Deskriptor/variabel yang dipakai meliputi beberapa jenis variabel antara lain moment dipol, berat molekul, jumlah cincin, dan indek konektivitas valensi sebagai variabel bebas. Metode yang digunakan untuk menguji keakuratan model persamaan yang diperoleh pada analisis regresi multilinier. Dalam hal ini yang digunakan adalah metode PRESS.

\section{Prediksi Senyawa PAH Lain Dengan Persamaan QSPR}

Setelah diketahui sifat-sifat kimia dan fisika dari senyawa yang dijadikan sebagai deskriptor yang memiliki pengaruh terhadap waktu retensi, maka berdasarkan parameter tersebut dapat diaplikasi kebeberapa senyawa $\mathrm{PAH}$ yang lain. Kemudian terhadap semua senyawa tersbut dilakukan perhitungan sesuai dengan metode yang digunakan pada penentuan persamaan QSPR. Waktu retensi teoritik log $\mathrm{t}_{R}$ dari senyawa hasil desain dihitung dengan menggunakan persamaan QSPR yang telah diperoleh.

\section{HASIL DAN PEMBAHASAN Perhitungan Data Deskriptor}

Untuk memperoleh data-data deskriptor dari struktur molekul sampel, terlebih dahulu dilakukan pemodelan 
dan kemudian dilakukan optimasi geometri terhadap molekul PAH. Pada proses optimasi geometri akan berlangsung minimasi energi suatu molekul ke tingkatan energi yang lebih rendah secara terus menerus sehingga dihasilkan struktur molekul dengan konformasi yang paling stabil. Sebagai contoh pada Gambar 1 ditunjukkan struktur molekul bifenil setelah dilakukan optimasi geometri.

Tabel 1. Hasil perhitungan deskriptor-deskriptor dengan metode ab-initio dengan himpunan basis 6-31G

\begin{tabular}{llcccccc}
\hline \multirow{2}{*}{ No } & \multicolumn{1}{c}{ Sampel senyawa } & Log t & \multicolumn{5}{c}{ Deskriptor-deskriptor } \\
& & & $\mu(\mathrm{D})$ & $\mathrm{MW}(\mathrm{sma})$ & $\mathrm{Rc}(\mathrm{n})$ & $\mathrm{X} 1(\mathrm{~m})$ & $\mathrm{X} 2(\mathrm{~m})$ \\
\hline 1 & Neopentil benzen & 1,505 & 0,332 & 148,247 & 1 & 4,118 & 4,223 \\
2 & 1,2,3,4-Tetrahidro naptalen & 2,524 & 0,534 & 272,389 & 4 & 7,934 & 6,220 \\
3 & Fluoren & 2,418 & 0,489 & 166,222 & 3 & 4,612 & 3,491 \\
4 & tetralin & 1,623 & 0,604 & 132,206 & 2 & 4,034 & 2,976 \\
5 & Heksahidropiren & 2,294 & 0,419 & 208,302 & 4 & 6,486 & 5,225 \\
6 & Bipenil & 2,173 & 0,000 & 154,211 & 2 & 4,071 & 2,732 \\
7 & 2-benzil naptalen & 2,531 & 0,136 & 218,298 & 3 & 5,933 & 4,344 \\
8 & Mesitilen & 1,672 & 2,005 & 120,194 & 1 & 3,232 & 2,665 \\
9 & Dodekahidrotri penilen & 2,161 & 0,000 & 240,388 & 4 & 7,934 & 6,493 \\
10 & Duren & 2,111 & 0,000 & 134,221 & 1 & 3,655 & 3,021 \\
11 & p-diksikloheksilbenzen & 1,544 & 0,046 & 242,403 & 3 & 8,032 & 6,337 \\
12 & 1,3 Dipenil propan & 2,134 & 0,267 & 196,291 & 2 & 5,528 & 3,825 \\
13 & 1,2,3,4-Tetrahidro penantren & 2,526 & 0,617 & 182,265 & 3 & 5,445 & 4,131 \\
14 & 2,3-Benzofluoren & 2,635 & 0,705 & 216,282 & 4 & 6,017 & 4,690 \\
15 & Toluen & 1,643 & 0,000 & 92,140 & 1 & 2,411 & 1,655 \\
16 & 4,4 Dimetil bipenil & 2,215 & 0,064 & 182,265 & 2 & 4,493 & 3,732 \\
17 & Penantren & 2,585 & 0,013 & 178,233 & 3 & 4,815 & 3,508 \\
18 & 4H-Siklopenta penantren & 2,628 & 0,568 & 190,244 & 4 & 5,356 & 4,273 \\
\hline
\end{tabular}

Perhitungan elektronik dan sifat-sifat fisik dari senyawa organik dapat dilakukan dengan berbagai cara tergantung dari jenis variabel/deskriptor yang akan digunakan. Dalam penelitian ini perhitungan deskriptor dibagi menjadi tiga kelompok. Kelompok pertama didasarkan pada pendekatan ab initio untuk mendapatkan parameter seperti moment dipol. Metode ab initio dipilih karena menghasilkan perhitungan panjang ikatan dan sudut ikatan yang relatif mendekati harga yang diperoleh melalui ekperimen. Untuk kelompok deskriptor kedua, perhitungan dilakukan dengan menggunakan program modeslab. Data deskriptor yang diperoleh adalah nilai indeks konektivias valensi baik orde 1 dan orde 2, sedangkan untuk kelompok ketiga perhitungan dilakukan untuk memperoleh data berat molekul dan jumlah cincin. Hasil perhitungan tiap deskriptor disajikan pada Tabel 1.

\section{Analisis statistik QSPR}

Untuk mengetahui hubungan antara deskriptordeskriptor atau parameter terpilih sebagai variabel bebas dengan log $t_{R}$ dari senyawa-senyawa sampel tersebut maka digunakan teknik analisis regresi multilinier. Sebelum dilakukan analisis hubungan antara deskriptor dengan waktu retensi, terlebih dahulu dilakukan pemilihan variabel. Variabel bebas yang dipilih adalah momen dipol, berat molekul, jumlah cincin, indeks konektivitas valensi orde 1 dan 2 . Pemilihan variabel bebas tersebut karena diketahui dan diyakini deskriptor-deskriptor mempengaruhi varibel tidak bebasnya yakni waktu retensi kromatografi dari senyawa-senyawa yang digunakan.

Persamaan QSPR yang dihasilkan dituliskan pada persamaan berikut ini:

$\log \mathrm{t}_{R}=1.123+0.016 \mathrm{MW}+0.353 \mathrm{Rc}-0.416 \mathrm{x}^{1}-0.162 \mathrm{x}^{2}$ dengan $n=15 r=0,951 ; r^{2}=0.905 ; S E=0,150$;

$\mathrm{F}_{\text {hitung }} / \mathrm{F}_{\text {tabel }}=6,837$

Persamaan model 2 memberikan garis lurus yang mendekati ideal, yaitu yang ditunjukkan dengan harga slopenya mendekati 1. Gambar 2 memperlihatkan grafik korelasi antara waktu retensi prediksi dengan waktu retensi eksperimen terhadap (a) data internal (fitting) dan (b) data eksternal (uji). 


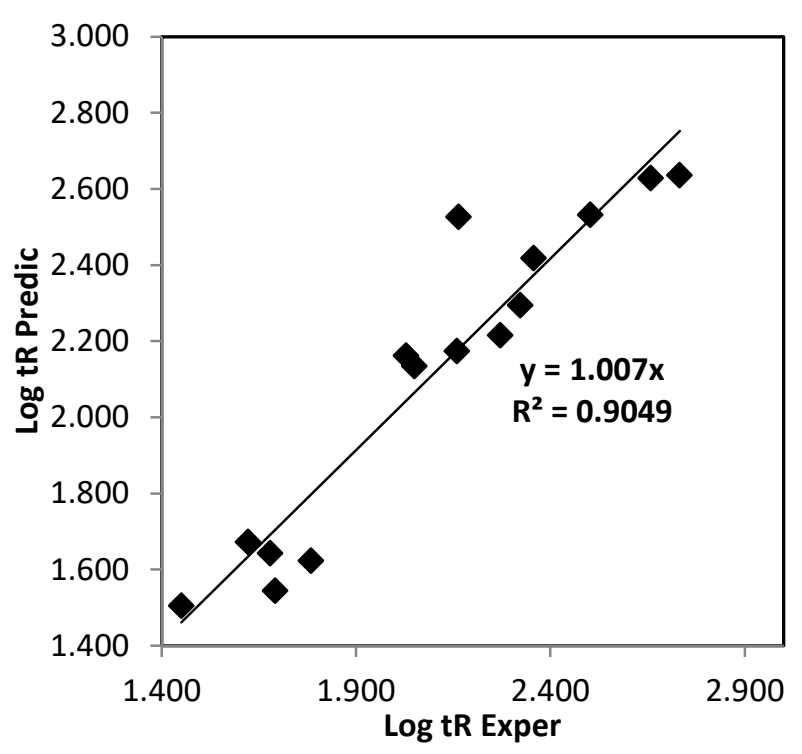

(a)

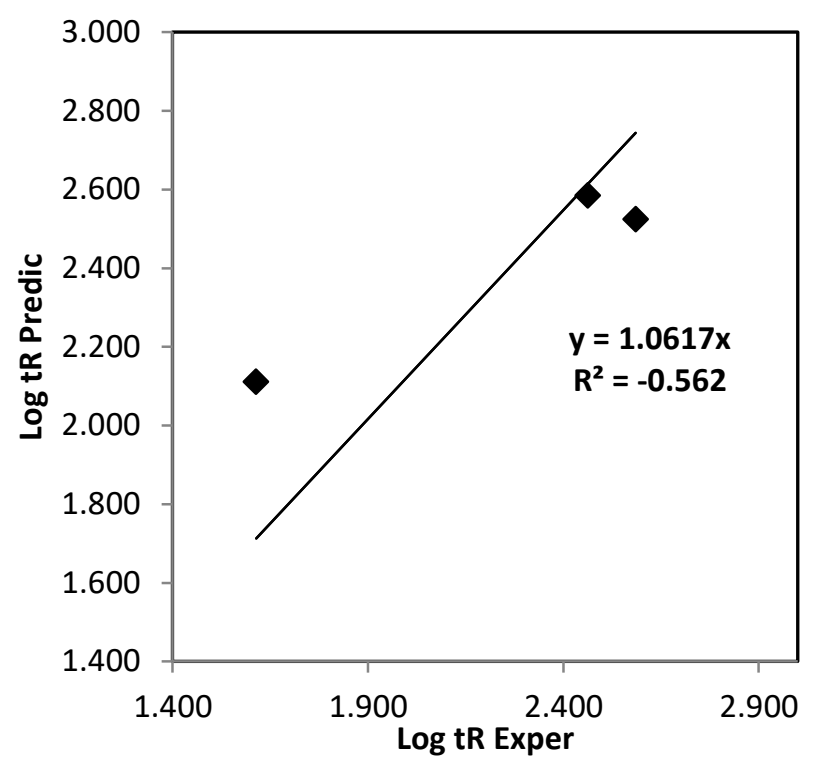

(b)

Gambar 2 Grafik korelasi antara waktu retensi $\left(\log t_{R}\right)$ prediksi dan waktu retensi $\left(\log t_{R}\right)$ eksperimen terhadap (a) data internal (fitting) dan (b) data eksternal uji.

Dari persamaan model 2 terlihat bahwa variabel yang berpengaruh terhadap nilai $\log t_{R}$ adalah berat molekul (MW), jumlah cincin ( $\mathrm{Rc}$ ), indeks konektivitas valensi orde $1\left(x^{1}\right)$, dan orde $2\left(x^{2}\right)$. Selanjutnya variabelvariabel inilah yang digunakan untuk merumuskan persamaan QSPR akhir dengan melibatkan total 18 senyawa. Hal ini dilakukan dengan pertimbangan semakin banyak data akan memberikan hasil yang representatif.

Perumusan persamaan QSPR akhir dilakukan berdasarkan deskriptor yang terlibat pada model yang terpilih yakni model 2 dan selanjutnya dilakukan analisis ulang menggunakan 18 senyawa dengan program SPSS for windows untuk mendapatkan model persamaan QSPR akhir terbaik dengan metode enter. Variabel bebas yang dilibatkan adalah berat molekul(MW), jumlah cincin(Rc), indeks konektivitas valensi orde $1\left(x^{1}\right)$, dan orde $2\left(x^{2}\right)$, sedangkan variabel tidak bebas yang digunakan adalah waktu retensi (log $\mathrm{t}_{R}$ ), sehingga didapatkan model persamaan QSPR terbaik.

Hasil regresi linier memberikan hasil yang cukup baik dengan nilai koefisien korelasi yang cukup tinggi, yaitu 0,940 . Hasil ini juga didukung oleh nilai SE yang kecil, yaitu 0,156 serta rasio $F_{\text {hitung }} / F_{\text {tabel }}$ yang cukup besar yakni 7,208. Grafik korelasi antara waktu retensi $\left(\log t_{R}\right)$ prediksi dan eksperimen yang tunjukkan pada Gambar 3 juga memperlihatkan slope yang mendekati 1. Ini berarti bahwa persamaan yang dihasilkan mampu memberikan tingkat prediksi yang cukup baik. Dari perhitungan menggunakan program SPSS dengan metode enter didapat persamaan QSPR sebagai berikut:

$\log \mathrm{t}_{R}=1,276+0,016 \mathrm{MW}+0,323 \mathrm{Rc}-0,423 \mathrm{x}^{1}-0,147 \mathrm{x}^{2}$ dengan $n=18 r=0,917 \quad r^{2}=0,841 \quad S E=0,182 \quad F_{\text {hitung }} / F_{\text {tabel }}$ $=5,408$

Notasi $n$ adalah jumlah senyawa yang dianalisis, $r$ adalah koefisien korelasi, $r^{2}$ adalah koefisien determinasi ganda, SD adalah standar deviasi dan $\mathrm{F}$ adalah ukuran perbedaan tingkat signifikansi dari model regresi. Dari persamaan di atas dapat dilihat bahwa deskriptor yang berpengaruh terhadap waktu retensi senyawa adalah berat molekul, jumlah cincin, indeks konektivitas valensi orde1 dan orde 2 . 


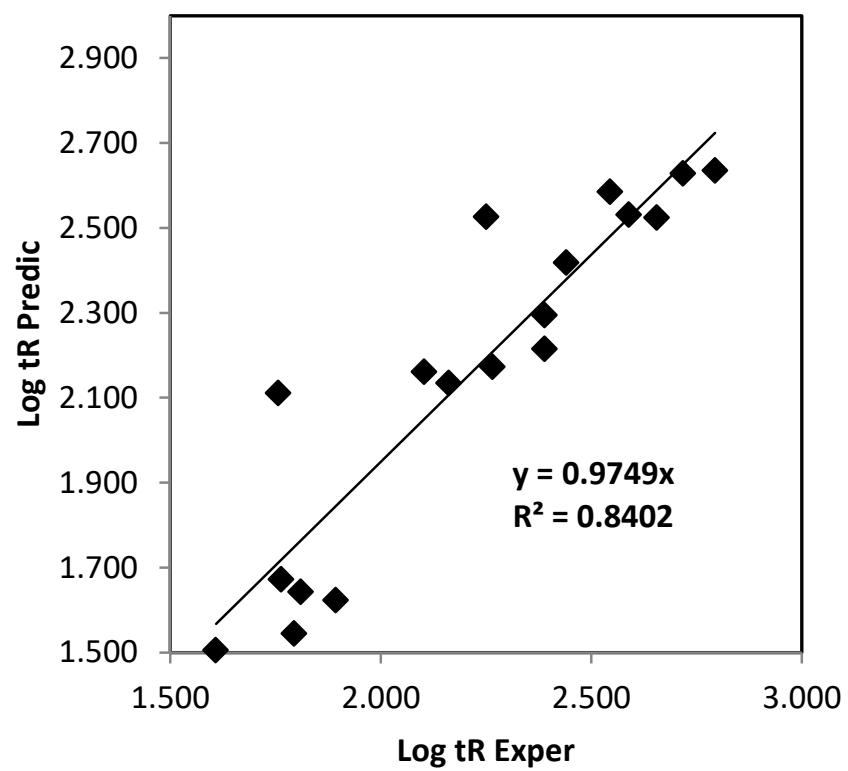

Gambar 3 Grafik korelasi antara waktu retensi $\left(\log t_{R}\right)$ prediksi dan eksperimen pada 18 senyawa.

Tabel 2 Hasil perhitungan deskriptor senyawa PAH dengan metode ab initio

\begin{tabular}{llcrrrr}
\hline \multicolumn{1}{c}{ Senyawa } & $\begin{array}{c}\mathrm{MW} \\
(\mathrm{sma})\end{array}$ & $\begin{array}{c}\mathrm{R}_{\mathrm{c}} \\
(\mathrm{n})\end{array}$ & $\mathrm{x} 1(\mathrm{M})$ & $\mathrm{x} 2(\mathrm{M})$ & $\begin{array}{c}\text { Log } \mathrm{t}_{R} \\
\text { Eksperimen }\end{array}$ & $\begin{array}{c}\operatorname{Log~}_{R} \\
\text { Prediksi }\end{array}$ \\
\hline Naptalen & 128,173 & 2 & 3,405 & 2,347 & 2,241 & 2,187 \\
2,6-Dimetil naptalen & 156,277 & 2 & 4,226 & 3,354 & 2,346 & 2,142 \\
Ace naptilen & 152,195 & 3 & 4,149 & 3,126 & 2,542 & 2,466 \\
Acenapten & 154,211 & 3 & 4,445 & 3,432 & 2,389 & 2,328 \\
\hline
\end{tabular}

Dari persamaan QSPR model 2, terdapat empat variabel yang memiliki korelasi terhadap besarnya waktu retensi senyawa poliaromatik hidrokarbon. Keempat variabel tersebut merupakan deskriptordeskriptor yang masing-masing memiliki pengaruh berbeda-beda terhadap besar kecilnya $t_{R}$ dari senyawa. Walaupun secara statistik keempat deskriptor tersebut dapat diterima, namun terdapat dua deskriptor yang paling signifikan mempengaruhi kenaikan $t_{R}$. Kedua deskriptor tersebut adalah berat molekul dan jumlah cincin, dengan demikian kedua deskriptor tersebut memiliki kontribusi nyata dan signifikan terhadap keberagaman harga $t_{R}$ senyawa. Untuk deskriptordeskriptor lainnya seperti dapat dikatakan memiliki kontribusi secara tidak langsung terhadap besarnya $t_{R}$.

\section{Prediksi Waktu Retensi Senyawa PAH Lain Dengan Persamaan QSPR}

Pada penelitian ini dilakukan prediksi senyawa $\mathrm{PAH}$ yang lain dengan persamaan QSPR yang telah diperoleh. Prediksi waktu retensi terhadap senyawa PAH yang dilakukan atas dasar pertimbangan deskriptor-deskriptor yang berpengaruh tersebut. Hasil percobaan prediksi waktu retensi pada senyawa PAH lainnya dapat dilihat pada Tabel 2.
Dari keempat senyawa yang dicobakan dalam persamaan QSPR yang diperoleh didapatkan bahwa nilai prediksi mempunyai selisih yang kecil dengan nilai ekperimennya. Dengan demikian model persamaan yang aplikasikan tersebut dapat dipilih sebagai model yang menghubungkan secara kuantitatif antara waktu retensi dengan deskriptor berat molekul, jumlah cinicin, dan indek konektivitas valensi.

\section{KESIMPULAN}

Dari hasil analisis QSPR yang telah dilakukan dapat ditarik kesimpulan sebagai berikut:

1. Hubungan antara struktur senyawa sampel dengan waktu retensi bersifat linearistik untuk kromatografi pada kondisi suhu ruangan menggunakan fase diam kolom silika DNAP dan fase gerak n-pentana dan metil klorida dengan variabel utama sifat struktur senyawa berupa berat molekul, jumlah cincin, dan indeks konektivitas valensi.

2. Dari hasil analisis QSPR menggunakan struktur sifat senyawa sebagai variabel bebas diperoleh persamaan QSPR terbaik yang menghubungkan sifat senyawa dengan waktu retensi adalah:

$\log \mathrm{t}_{R}=1,276+0,016 \mathrm{MW}+0,323 \mathrm{Rc}-0,423 \mathrm{x}_{1}$ $0,147 x^{2}$

$\mathrm{n}=18 \quad \mathrm{r}=0,917 \quad \mathrm{r} 2=0,841 \quad \mathrm{SE}=0,182$

Fhitung/Ftabel $=5,408$ 
3. Berdasarkan model QSPR di atas telah dicobakan prediksi waktu retensi terhadap senyawa PAH golongan cincin 2 dan 3 . Hasil prediksi menunjukkan selisih yang kecil terhadap nilai eksperimen.

\section{DAFTAR PUSTAKA}

1. Abdel-Shafy, H. I., \& Mansour, M. S. (2016). A review on polycyclic aromatic hydrocarbons: source, environmental impact, effect on human health and remediation. Egyptian Journal of Petroleum, 25(1), 107-123.

2. Rubio-Clemente, A., Torres-Palma, R. A., \& Peñuela, G. A. (2014). Removal of polycyclic aromatic hydrocarbons in aqueous environment by chemical treatments: a review. Science of the Total Environment, 478, 201-225.

3. Berntssen, M. H. G., Ørnsrud, R., Hamre, K., \& Lie, K. K. (2015). Polyaromatic hydrocarbons in aquafeeds, source, effects and potential implications for vitamin status of farmed fish species: a review. Aquaculture Nutrition, 21(3), 257-273.

4. Lamichhane, S., Krishna, K. B., \& Sarukkalige, R. (2016). Polycyclic aromatic hydrocarbons (PAHs) removal by sorption: a review. Chemosphere, 148, 336-353.

5. Ranc, B., Faure, P., Croze, V., \& Simonnot, M. O. (2016). Selection of oxidant doses for in situ chemical oxidation of soils contaminated by polycyclic aromatic hydrocarbons (PAHs): A review. Journal of hazardous materials, 312, $280-$ 297.

6. Golmohammadi, H., Dashtbozorgi, Z., \& Vander Heyden, Y. (2015). Support vector regression based QSPR for the prediction of retention time of peptides in reversed-phase liquid chromatography. Chromatographia, 78(1-2), 7-19.

7. Dossin, E., Martin, E., Diana, P., Castellon, A., Monge, A., Pospisil, P., \& Guy, P. A. (2016). Prediction models of retention indices for increased confidence in structural elucidation during complex matrix analysis: application to gas chromatography coupled with high-resolution mass spectrometry. Analytical chemistry, 88(15), 7539-7547.

8. Hu, J., Zhang, X., \& Wang, Z. (2010). A review on progress in QSPR studies for surfactants. International journal of molecular sciences, 11(3), 1020-1047.

9. Dashtbozorgi, Z., Golmohammadi, H., \& Konoz, E. (2013). Support vector regression based QSPR for the prediction of retention time of pesticide residues in gas chromatography-mass spectroscopy. Microchemical Journal, 106, 51-60.

10. Ghasemi, J., \& Saaidpour, S. (2009). QSRR prediction of the chromatographic retention behavior of painkiller drugs. Journal of chromatographic science, 47(2), 156-163.

11. Drosos, J. C., Viola-Rhenals, M., \& Vivas-Reyes, R. (2010). Quantitative structure-retention relationships of polycyclic aromatic hydrocarbons gas-chromatographic retention indices. Journal of Chromatography A, 1217(26), 4411-4421.

12. Kaliszan, R., \& Bączek, T. (2010). QSAR in chromatography: quantitative structure-retention relationships (QSRRs). In Recent Advances in QSAR Studies (pp. 223-259). Springer Netherlands.

13. Marrero-Ponce, Y., Barigye, S. J., JorgeRodríguez, M. E., \& Tran-Thi-Thu, T. (2017). QSRR prediction of gas chromatography retention indices of essential oil components. Chemical Papers, 1-13.

14. Rojas, C., Duchowicz, P. R., Tripaldi, P., \& Diez, R. P. (2015). Quantitative structure-property relationship analysis for the retention index of fragrance-like compounds on a polar stationary phase. Journal of Chromatography A, 1422, 277288.

15. Torrens, F., \& Castellano, G. (2018). QSPR prediction of retention times of methylxanthines and cotinine by bioplastic evolution. International Journal of Quantitative Structure-Property Relationships (IJQSPR), 3(1), 74-87.

16. Chao, K. P., Wang, V. S., Liu, C. W., \& Lu, Y. T. (2017). QSAR studies on partition coefficients of organic compounds for polydimethylsiloxane of solid-phase microextraction devices. International Journal of Environmental Science and Technology, 1-10.

17. Ghosh, P., Chawla, B., Joshi, P. V., \& Jaffe, S. B. (2006). Prediction of chromatographic retention times for aromatic hydrocarbons. Energy \& fuels, 20(2), 609-619. 